\title{
Healing of pathological fracture in a case of multiple myeloma
}

\author{
Raju Vaishya, Vipul Vijay, Amit Kumar Agarwal
}

Department of Orthopaedic and Joint Replacement Surgery, Indraprastha Apollo Hospitals, New Delhi, Delhi, India

\section{Correspondence to} Professor Raju Vaishya, raju.vaishya@gmail.com

Accepted 27 December 2016

CrossMark

To cite: Vaishya $R$, Vijay $V$, Agarwal AK. BMJ Case Rep Published online: [please include Day Month Year] doi:10.1136/bcr-2016218672

\section{DESCRIPTION}

A man aged 41 years presented to us with a lytic lesion in the proximal humerus and developed a pathological fracture which was managed with nailing (figure 1). He was eventually diagnosed with multiple myeloma. ${ }^{1}$ This patient underwent autologous bone marrow transplant. He was also given chemotherapy using a regimen of bortezomib, lenalidomide and dexamethasone. The humeral fracture showed sound union at the follow-up of 1.5 years with the lesion completely healed (figure 2).

The humerus is a common site for metastatic bone disease and the common primaries include breast, lung, multiple myeloma, etc. Multiple myeloma has shown improved long-term survival rates due to recent advances in treatment options. The improvement in survival rates has also been attributed to introduction of novel therapies early in the treatment course. Gainor and Buchert ${ }^{2}$ reported a union rate of $67 \%$ of fractures in pathological fractures associated with multiple myeloma.

Recently, International Myeloma Working Group had identified various factors which can help in risk stratification. They suggested that age at presentation and the response to treatment are the most important factors affecting a successful outcome. ${ }^{3}$

In the present patient also, the young age at presentation, a good response to chemotherapy and bone marrow transplant, along with a rigid fixation of the fracture helped to achieve a good functional outcome. Locked intramedullary nailing can provide stable fixation of the pathological fractures of humerus. The fixation should be followed up with recommended radiotherapy and chemotherapy protocols.
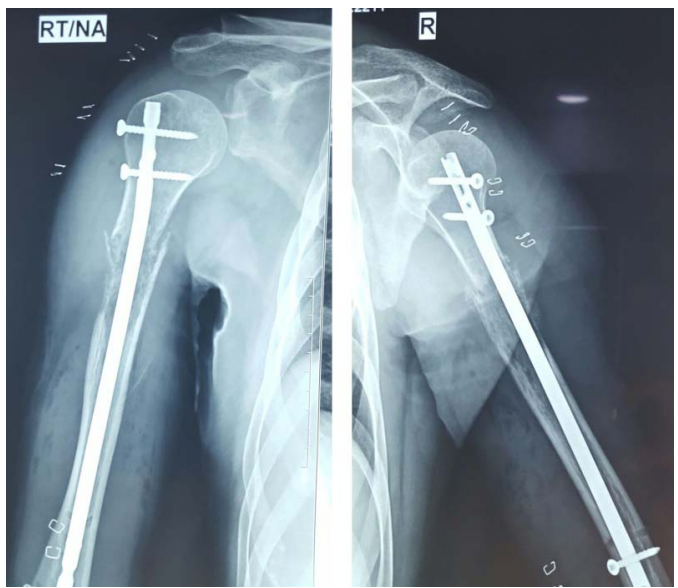

Figure 1 The immediate postoperative radiograph of the fracture showing the internal fixation of the pathological fracture with a locked intramedullary nail.
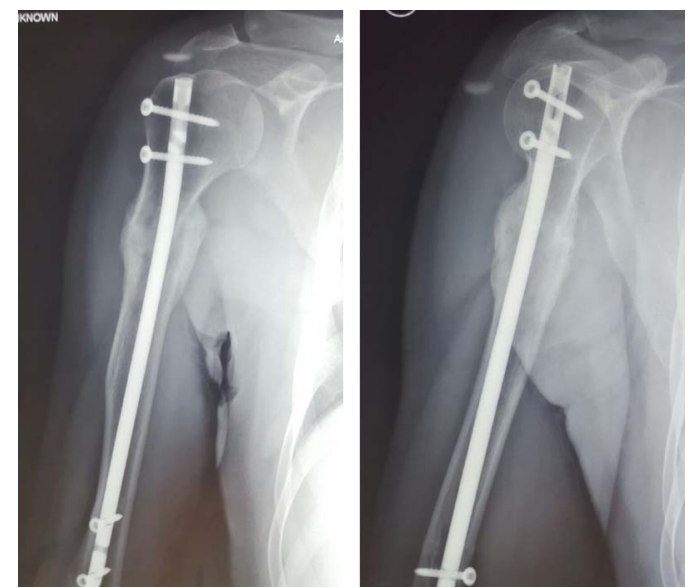

Figure 2 One-and-a-half-year follow-up radiograph of the same patient showing sound union with complete resolution of the pathological lesion.

\section{Learning points}

Pathological fractures of long bones can be satisfactorily treated with internal fixation with adequate adjuvant therapy.

- The fracture union depends on multiple factors, including the nature of the primary malignancy, survival duration, etc.

- Pathological fracture of the humerus should be treated by using interlocking nails, even though the origin of the cancer such as myeloma or lung cancer is an unfavourable disease.

- Pathological fractures associated with multiple myeloma have a favourable union rate among all the common metastasis.

Contributors RV helped in the conceptualisation and preparation of the manuscript. VV helped in the preparation of the manuscript and data acquisition. AKA helped in the preparation of the manuscript and data acquisition.

Competing interests None declared.

Patient consent Obtained.

Provenance and peer review Not commissioned; externally pee reviewed.

\section{REFERENCES}

1 Vaishya $R$, Agarwal AK, Vijay V. Lessons learnt from a case of multiple myeloma. BMJ Case Rep 2015;2015:m.n.

2 Gainor BJ, Buchert P. Fracture healing in metastatic bone disease. Clin Orthop Relat Res 1983(178):297-302.

3 Chng WJ, Dispenzieri A, Chim CS, et al., International Myeloma Working Group. IMWG consensus on risk stratification in multiple myeloma. Leukemia 2014;28:269-77. 
Copyright 2017 BMJ Publishing Group. All rights reserved. For permission to reuse any of this content visit http://group.bmj.com/group/rights-licensing/permissions.

BMJ Case Report Fellows may re-use this article for personal use and teaching without any further permission.

Become a Fellow of BMJ Case Reports today and you can:

- Submit as many cases as you like

- Enjoy fast sympathetic peer review and rapid publication of accepted articles

- Access all the published articles

- Re-use any of the published material for personal use and teaching without further permission

For information on Institutional Fellowships contact consortiasales@bmjgroup.com

Visit casereports.bmj.com for more articles like this and to become a Fellow 